\title{
Waardenburg syndrome type 1
}

INSERM

\section{Source}

INSERM. (1999). Orphanet: an online rare disease and orphan drug data base.

Waardenburg syndrome type 1. ORPHA:894

Waardenburg syndrome type 1 (WS1) is a subtype of Waardenburg syndrome (WS; see this term), disorder characterized by cong enital deafness, minor defects in structures arising from neural crest resulting in pigmentation anomalies of eyes, hair, and skin, in combination with dystopia canthorum. 